\title{
Women oppose sin stocks more than men do
}

\author{
Paweł Niszczota ${ }^{\mathrm{a},},{ }^{*}$, Michał Białek ${ }^{\mathrm{b}}$
}

Accepted for publication in Finance Research Letters

${ }^{a}$ Poznań University of Economics and Business; Department of International Finance

${ }^{\mathrm{b}}$ University of Wrocław; Institute of Psychology

* Corresponding author: Paweł Niszczota, Poznań University of Economics and Business, al. Niepodległości 10, 61-875, Poznań, Poland; pawel.niszczota@ue.poznan.pl; ORCID: 0000-0002-4150-3646

\section{Acknowledgments}

This research has been supported by grants 2018/31/D/HS4/01814 and 2018/02/X/HS4/01703 from the National Science Centre, Poland.

\section{Open Science Practices}

This study has been pre-registered. The pre-registration document, data and materials are available at: https://osf.io/74j39/. 


\title{
Women oppose sin stocks more than men do
}

\begin{abstract}
We experimentally test whether men and women differ in their propensity to hold morally controversial ("sin") stocks. Participants $(N=335)$ were recruited via Mechanical Turk and rated the moral appropriateness and level of comfort resulting from holding controversial and conventional stocks. Results show that women rate sin stocks as less morally appropriate investment propositions and feel considerably less comfortable investing in controversial (but not conventional) stocks. Sex differences in sin stock tolerance were substantial $(d=.60)$ and remained significant after accounting for differences in investment knowledge and risk tolerance. We discuss two important outcomes of these differences.
\end{abstract}

Keywords: behavioral finance; experimental finance; sin stocks; socially responsible investing; investment funds; sex differences; moral inclinations; judgment and decision making

\section{Introduction}

"Sin" stocks are public companies that engage in socially or morally objectionable activities (Luo and Balvers, 2017). While earlier the list of sin stocks was limited to companies involved in the production of alcohol, tobacco or gambling (the "triumvirate of sin"), now the list is longer and includes, for example, companies involved in the production of meat, fast-food, embryonic stem cells, marijuana or coal (Fabozzi et al., 2019; Trinks et al., 2018; Trinks and Scholtens, 2017; Weisskopf, 2020). A company can also be considered a "sinner" if it itself, or even its CEO, engages in acts of socially irresponsible behavior. Interestingly, there is research showing that refusing to invest in sin stocks can be economically costly, since such stocks can produce a considerably higher return than investments in non-sin stocks (an alternative perspective is that not investing in sin stocks leads to lower expected returns; see: Hong and Kacperczyk, 2009; Fabozzi, Ma and Oliphant, 2008).

Past research established that people are less eager to invest in sin stocks, especially institutional investors (Hong and Kacperczyk, 2009). In this paper we ask whether this effect is greater in women. Preliminary evidence comes from our earlier study (Niszczota and Kaszás, 2020), in which participants assessed their attitudes toward fourteen controversial industries from Trinks and Scholtens (2017). While analyzing our data, we observed that women felt significantly less comfortable with the perspective of investing in each of the controversial industries (see Fig. 1A). The current study aims to replicate those findings in a pre-registered and controlled fashion. 
A

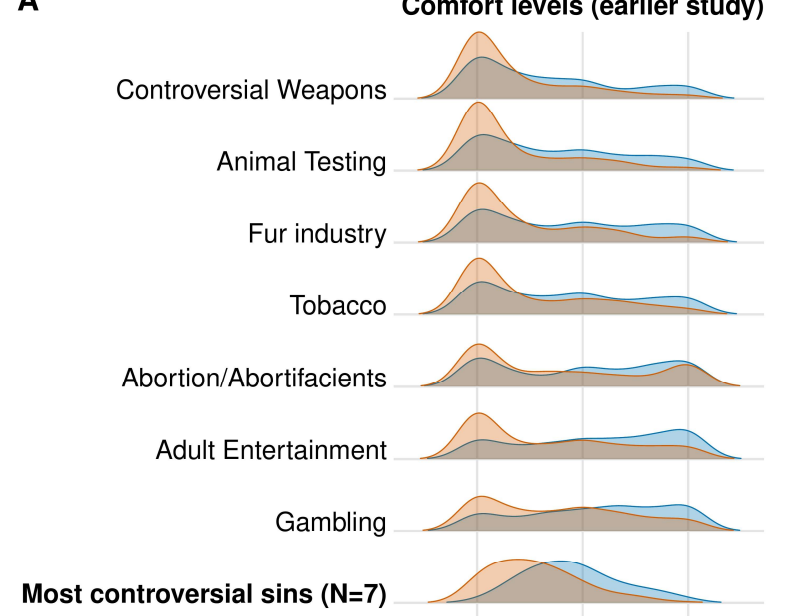

Most controversial sins $(\mathrm{N}=7)$

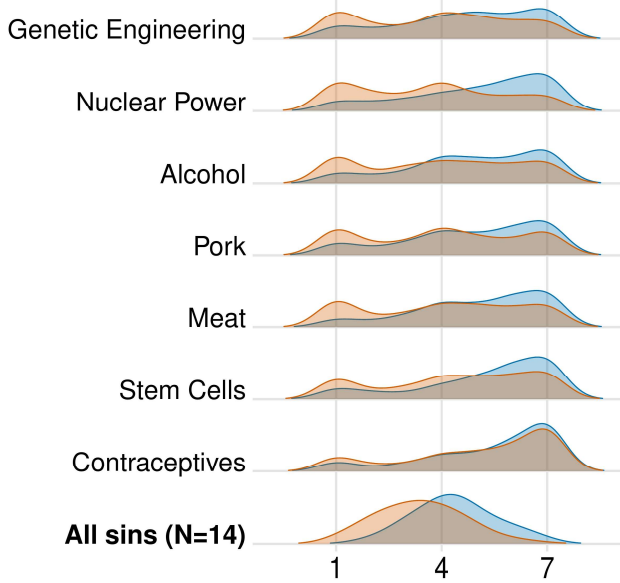

B Moral appropriateness

7 -

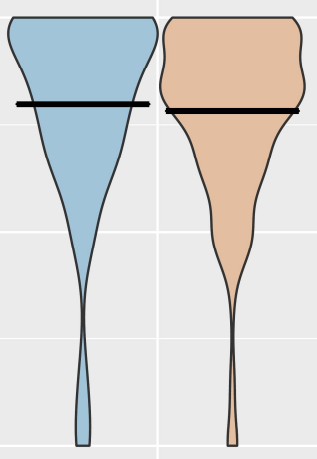

Conventional

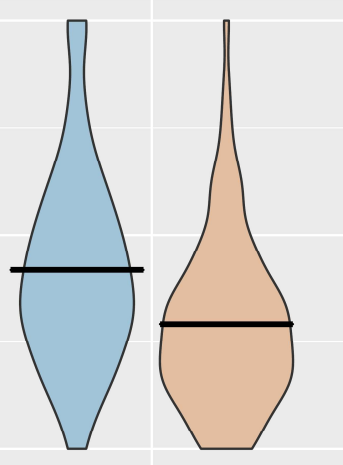

$\operatorname{Sin}$

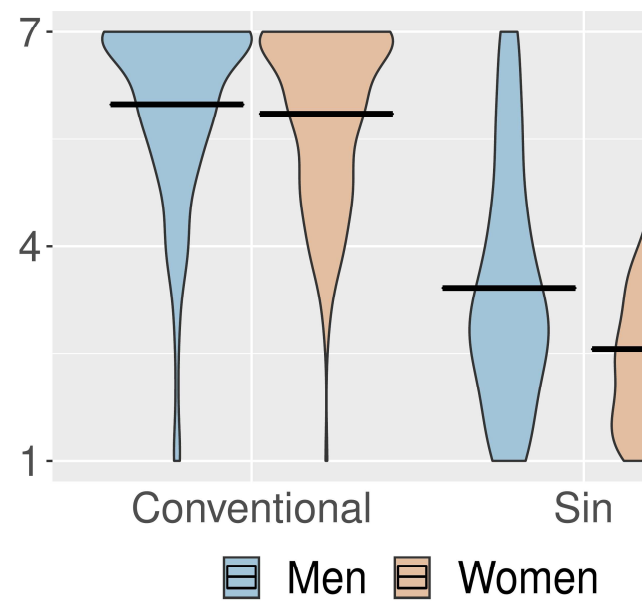

Fig. 1. Moral appropriateness and/or comfort levels of holding stocks, in earlier study (A) and current study (B). Panel A shows data from our earlier study (Niszczota and Kaszás, 2020) that investigated $14 \mathrm{sin}$ industries from Trinks and Scholtens (2017). Here, the sins are presented in descending order (from most to least controversial, based on the mean rating in that sample). Panel B shows data for the current study ( 7 sin industries with which participants felt the least comfortable with in the earlier study). Horizontal bars indicate means.

If sex differences actually exist, they would be important for at least two reasons. Firstly, this could contribute to the long-term differences between the wealth of men and women. Sin stocks comprise $7 \%$ of all stocks in the US (by market capitalization), using a broader industry-based definition of sin stocks (Trinks and Scholtens, 2017). The exclusion of such stocks might have severe financial repercussions, as a recent study has shown that the best-performing $4 \%$ of companies explain the gain in the entire US stock market (Bessembinder, 2018). Secondly, differences in the propensity to invest in sin stocks will likely indicate that men and women will differ in their corporate decisions. For example, when choosing projects, female executives would be less likely to choose a project that might be morally controversial or to approve an acquisition of a morally controversial company.

\section{Experiment}

\subsection{Participants}

We recruited Mechanical Turk participants that were residents of the United States, and had at least $95 \%$ out of a minimum 1000 tasks approved. We used a power analysis to estimate the required sample size that would yield a very high probability of finding an effect if it exists 
(i.e., avoiding a Type II error $(\beta)$ ). More specifically, we wanted to achieve $1-\beta=.95$ power $(\alpha=.05)$ to detect a small effect in the interaction of interest $(f=.10$, repeated measures, withinbetween interaction, $n_{\text {groups }}=2, n_{\text {measurements }}=2$ ). The $\mathrm{G}^{*}$ Power analysis (Faul et al., 2009) yielded $N=328$ as the desired sample size. Accordingly, we collected data from 364 participants to account for an expected $\sim 10 \%$ exclusion rate of inattentive participants. We ultimately excluded 29 participants that did not pass a single-choice test question, where they identified which of four industries was not presented to them in the experiment. We conducted the analyses on the remaining 335 participants $\left(M_{\text {age }}=38.7\right.$ years, $\left.S D=12.6\right), 188(56 \%)$ of whom were female. Informed consent was obtained from all participants and the experiment adhered to appropriate guidelines.

\subsection{Materials and methods}

Participants were presented with the seven most controversial industries from our earlier study (out of fourteen from Trinks and Scholtens (2017)), and with seven conventional industries (see the Appendix for their descriptions). We asked participants to judge the moral appropriateness of holding stocks from each of the industries (Would it be morally appropriate if you invested in companies from the following industries?) and how comfortable they would feel if their pension fund invested in these stocks (Would you feel comfortable if your pension fund invested in companies from the following industries?). For both types of judgments, participants used a 7-point Likert scale, with endpoints labelled 1 (not at all) and 7 (completely). For each judgment, we averaged these ratings within each stock type (i.e., sin vs conventional), creating two indexes for each participant. All analyses were conducted on these indexes.

Participants then stated their age and biological sex, and answered two items that assessed their subjective risk tolerance (Dohmen et al., 2011) and their subjective investment knowledge. Additionally, participants completed a six-item investment knowledge test that was meant to assess their objective investment knowledge (e.g., Considering a long time period (e.g., 10 or 20 years), which asset normally gives the highest return: savings accounts, bonds or stocks? (van Rooij et al., 2011)).

We employed a quasi-experimental design, i.e. one in which we could not manipulate the key variable (biological sex), but it was "assigned" randomly to participants by nature. We used a mixed-model analysis of variance, as it combined both factors that varied across participants (biological sex) and within participants (stock type). This allowed us to test whether men and women differ in their judgment of sin stocks, also taking into account potential differences in the judgment of conventional stocks (which served as controls). We also used mediation analyses when testing whether sex differences in sin stock aversion are confounded with sex differences in risk tolerance and investment knowledge.

This study was pre-registered. The pre-registration document, data and materials are available at: https://osf.io/74j39/.

\section{Results}

In Table 1, we provide preliminary tests of sex differences, using Cohen's $d$ as a measure of the effect sizes (along with 95\% confidence intervals). Cohen's $d$ describes the differences between two means divided by the pooled standard deviation of these means. For example, a difference of 5 IQ points between two groups with a $S D=15$ is equal to $d=0.33$, and in psychological research it can be considered a moderate effect size (Funder and Ozer, 2019). Alternatively, $d=0.33$ means that a person randomly drawn from the higher scoring group is $59.2 \%$ likely to have a higher IQ score than a person randomly drawn from the lower scoring group. 
Table 1. Sex differences observed in the current study

\begin{tabular}{|c|c|c|c|c|c|}
\hline & & Men & Women & $d[95 \% \mathrm{CI}]$ & $t$ \\
\hline \multirow[t]{2}{*}{ Moral appropriateness } & Conventional & $\begin{array}{c}5.79 \\
(1.44)\end{array}$ & $\begin{array}{c}5.69 \\
(1.25)\end{array}$ & $\begin{array}{c}-0.07 \\
{[-0.29,0.15]}\end{array}$ & -0.63 \\
\hline & Sin & $\begin{array}{c}3.51 \\
(1.37) \\
\end{array}$ & $\begin{array}{c}2.75 \\
(1.18) \\
\end{array}$ & $\begin{array}{c}-0.59 * * * \\
{[-0.82,-0.37]}\end{array}$ & -5.30 \\
\hline \multirow[t]{2}{*}{ Comfort levels } & Conventional & $\begin{array}{c}5.99 \\
(1.29)\end{array}$ & $\begin{array}{c}5.86 \\
(1.17)\end{array}$ & $\begin{array}{c}-0.11 \\
{[-0.32,0.11]}\end{array}$ & -0.97 \\
\hline & Sin & $\begin{array}{c}3.42 \\
(1.64) \\
\end{array}$ & $\begin{array}{c}2.56 \\
(1.20) \\
\end{array}$ & $\begin{array}{c}-0.61 * * * \\
{[-0.83,-0.39]}\end{array}$ & -5.32 \\
\hline \multicolumn{2}{|l|}{ Risk tolerance } & $\begin{array}{l}5.15 \\
(2.35)\end{array}$ & $\begin{array}{l}4.20 \\
(2.37)\end{array}$ & $\begin{array}{c}-0.40 * * * \\
{[-0.62,-0.18]}\end{array}$ & -3.67 \\
\hline \multicolumn{2}{|c|}{ Subjective investment knowledge } & $\begin{array}{l}4.20 \\
(1.55)\end{array}$ & $\begin{array}{c}3.37 \\
(1.56)\end{array}$ & $\begin{array}{c}-0.54 * * * \\
{[-0.76,-0.31]}\end{array}$ & -4.87 \\
\hline \multicolumn{2}{|c|}{ Objective investment knowledge } & $\begin{array}{c}4.61 \\
(1.34)\end{array}$ & $\begin{array}{c}4.30 \\
(1.25)\end{array}$ & $\begin{array}{c}-0.24 * \\
{[-0.46,-0.03]}\end{array}$ & -2.20 \\
\hline
\end{tabular}

Notes: Descriptive statistics are presented as means (standard deviations). $d$ corresponds to Cohen's $d$, with $95 \%$ confidence intervals presented in the square brackets. $t$ denotes statistic in Welch's $t$-test for equality of means (in men and women). $* * *$ and $*$ denote that differences are statistically significant at the $0.1 \%$ and $5 \%$ level, respectively.

As preregistered, for both of our dependent variables we performed a 2 (stock type, withinsubject $) \times 2$ (biological sex, between-subject) mixed-model ANOVA. We expected women to be more averse towards sin stocks than men, while having similar attitudes towards conventional stocks, which would translate into a stock type by sex interaction. Both tests confirmed our predictions (see Fig. 1B).

For moral appropriateness, there was a main effect of stock type, $F(1,333)=724.24, p<.001$, with investment in sin stocks rated less morally appropriate than investment in conventional stocks. There was also a main effect of sex, $F(1,333)=15.97, p<.001$, suggesting that men and women judged stocks differently. Consistent with our hypothesis, there was an interaction between sex and stock type, $F(1,333)=11.58, p<.001$. This corresponds to the crucial observation, that women judged investing in sin stocks as less morally appropriate than men did, while there were no differences between the sexes in the moral appropriateness ratings of conventional stocks (see Table A.1 for an industry-level comparison).

The results are qualitatively similar when comfort levels are used as the dependent variable, which is not surprising, considering that moral appropriateness of investing and the comfort of holding stocks are highly correlated $(r=.86, t(668)=44.1, p<.001$; this suggests that both judgments tap into the same construct). An analysis of variance showed a main effect of stock type $(F(1,333)=1036.48, p<.001)$, sex $(F(1,333)=19.04, p<.001)$ and an interaction between sex and stock type $(F(1,333)=15.88, p<.001)$. Once again, this corresponds to a crucial pattern: women judged that they would feel less comfortable than men if their pension fund invested in sin stocks, and there was the absence of such differences for conventional stocks. In Fig. A.1, we show how comfort level ratings from the current study compare with data from the earlier study.

Having established the presence of sex differences in sin stock aversion, we sought to test for its causes. Past literature suggests that women are less risk tolerant than men (e.g., Charness and Gneezy, 2012; Dohmen et al., 2011). We also observed such a difference in the current research. Women also assessed their investment knowledge to be worse than men did, although 
a six-question assessment of participants' objective investment knowledge suggested that actual differences between women and men are relatively small $(d=-0.24)$. These differences could potentially explain the gap in attitudes toward sin stocks. For example, female participants could perceive sin stocks as riskier, and therefore be more averse to investing in them. Alternatively, our female participants could lack adequate investment expertise, and therefore apply a simple heuristic of avoiding such stocks.

To test these possibilities, we ran two mediation analyses explaining the moral appropriateness and comfort of investing in sin stocks. We entered risk tolerance and objective investment knowledge as parallel mediators (Fig. 2). Our main interest is the extent to which sex differences in sin stock aversion are due to differences in risk tolerance and investment knowledge. In our mediation analyses, $c$ describes the overall effect of sex differences on sin stock aversion, and $c$ ' describes how much of the effect is direct, i.e. not explained by individual differences in risk tolerance and investment knowledge. Full mediation is when the $c$ ' parameter is non-significant, suggesting that differences are fully explained by mediators (i.e., are due to an indirect effect).

The analysis showed that although risk tolerance significantly predicted sin stock aversion, overall, the indirect effect (the $c$ - $c^{\prime}$ differential) was small $\left(c-c^{\prime}\right.$ moral $=0.17[0.07,0.29]$; $c-c^{\prime}$ comfort $\left.=0.16[0.06,0.29]\right)$. This is a case of partial mediation, in which the effect is explained by mediators only to a limited extent.

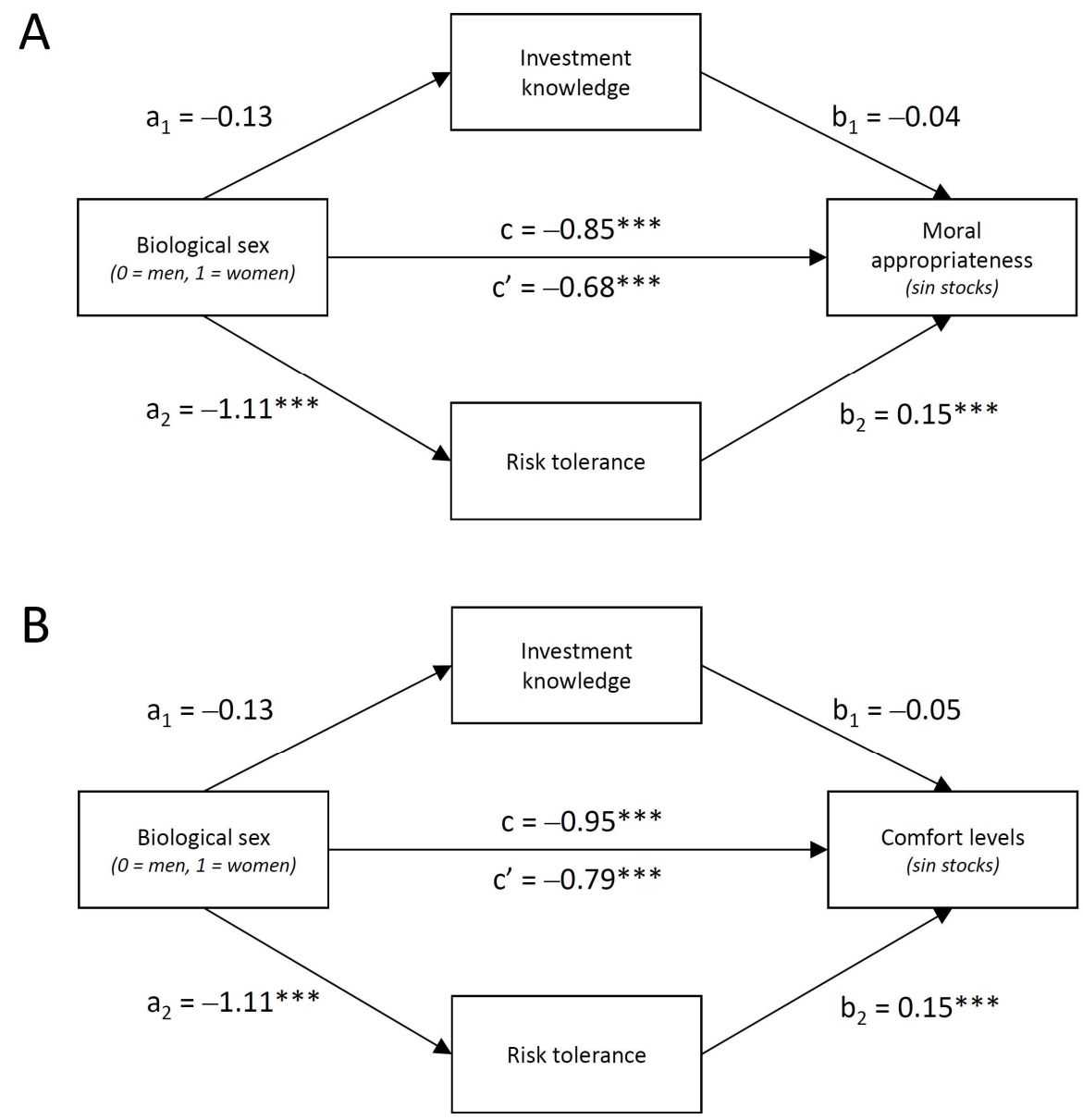

Fig. 2. Mediation models explaining the sex differences in sin stock aversion. Panel A presents the prediction model of moral appropriateness of investing in sin stocks. Panel B presents the prediction model of comfort levels associated with holding sin stocks. Regression coefficients are unstandardized. The analyses were done using the process macro (Preacher and Hayes, 2004). *** denotes statistical significance at the $0.1 \%$ level. 


\section{Discussion}

Our analysis yielded a difference in sin stock aversion across sexes roughly equal to 0.60 of a standard deviation, which persisted after accounting for differences in investment knowledge and risk tolerance between men and women. Based on extant research, it should be interpreted as large (using the $r=.30(d=0.63)$ threshold proposed by Funder and Ozer (2019)). To give more context, the $d=0.60$ sex difference in sin stock tolerance exceeds the well-documented and considerable size of sex differences in risk tolerance ( $d=0.40$ in our sample).

These differences can potentially be explained by the fact that women have stronger deontological inclinations then men, but similar utilitarian inclinations (Friesdorf et al., 2015). The size of the difference in deontological inclinations $(d=0.57)$ roughly corresponds to the sex differences in sin stock aversion. Deontology is a moral philosophy that judges acts as moral or immoral if they follow an abstract moral principle, e.g., "cause no harm" (Kant, 1785/1948). Deontology often reflects aversion to causing harm (Royzman and Baron, 2002), and acceptance of social norms (Gawronski et al., 2017). Utilitarianism, on the other hand, is a moral philosophy that judges acts as moral or immoral depending on their consequences: things that increase overall happiness in a group of people are considered moral even if they cause harm to some individuals (Mill, 1861/2016). To better illustrate this, torture that leads to saving lives by preventing a terrorist attack is permissible from a utilitarian, but not a deontological perspective. Similarly, investing in sin stocks might not be permissible from the deontological perspective, but might be permissible from the utilitarian perspective.

A limitation to our findings is that we did not collect more demographic information about our sample (e.g., income levels), and did not test active individual investors but laypeople. Moreover, we showed that people consider holding sin stocks as inappropriate and discomforting, but do not show that these preferences affect people's actual investment decisions. Moral preferences do not always align with decisions (Bonnefon et al., 2016). Finally, women with similar moral norms to men might self-select into the financial or corporate world (van Staveren, 2014) or may adopt less deontological (and more utilitarian) norms after entering it.

\section{Conclusions}

The current study shows that women judge controversial stocks more harshly than men, and feel less comfortable holding them in portfolios. This can have far reaching economic consequences. One likely outcome is that money accumulated in funds that were picked by female investors will underperform, as only a very limited number of companies are responsible for the equity premium (Bessembinder, 2018). Sin stock aversion can be problematic, as it appears that more and more companies might be considered sin stocks in the future. To illustrate, the day after the CEO of Tesla Inc. appeared to smoke marijuana during an interview, the stock price of the company fell by $6.3 \%$. It is believed that the two are connected (Higgins, 2018). Even though marijuana is now legal in many territories, some consider its producers to be "sin stocks" (Blitz and Fabozzi, 2017; Weisskopf, 2020). Sex differences in attitudes towards controversial companies might also affect "sin bond" prices (Fabozzi et al., 2019).

A second important outcome concerns corporate decisions in the future. A timely illustration is the declaration made by the CEO of Goldman Sachs, a major investment bank and also underwriter, that the company will refuse to facilitate IPOs of companies that do not have at least one diverse board member. This is essentially the rejection of an exclusively-male board (New York Times, 2020). As a result, corporate policies should change. For example, an 
increase in the number of female board members should decrease acquisitions of socially irresponsible companies (Guidi et al., 2020), and increase mimicry of corporate social responsibility policies (Cao et al., 2019). Such shifts in the composition of investors and corporate decision-makers might become tipping points, just as the number of "green" investors in the investor population - that find severe pollution by a company to be unacceptable - might determine whether a company reforms or not (Heinkel et al., 2001).

\section{References}

Bessembinder, H., 2018. Do stocks outperform Treasury bills? J. Financ. Econ. 129, 440-457. https://doi.org/10.1016/j.jfineco.2018.06.004

Blitz, D., Fabozzi, F.J., 2017. Sin Stocks Revisited: Resolving the Sin Stock Anomaly. J. Portf. Manag. 44, 105-111. https://doi.org/10.3905/jpm.2017.44.1.105

Bonnefon, J.-F., Shariff, A., Rahwan, I., 2016. The social dilemma of autonomous vehicles. Science 352, 1573-1576. https://doi.org/10.1126/science.aaf2654

Cao, J., Liang, H., Zhan, X., 2019. Peer Effects of Corporate Social Responsibility. Manage. Sci. 65, 5487-5503. https://doi.org/10.1287/mnsc.2018.3100

Charness, G., Gneezy, U., 2012. Strong Evidence for Gender Differences in Risk Taking. J. Econ. Behav. Organ., Gender Differences in Risk Aversion and Competition 83, 50-58. https://doi.org/10.1016/j.jebo.2011.06.007

Dohmen, T., Falk, A., Huffman, D., Sunde, U., Schupp, J., Wagner, G.G., 2011. Individual Risk Attitudes: Measurement, Determinants, and Behavioral Consequences. J. Eur. Econ. Assoc. 9, 522-550. https://doi.org/10.1111/j.1542-4774.2011.01015.x

Fabozzi, F.J., Lamba, A.S., Nishikawa, T., Rao, R.P., Ma, K.C., 2019. Does the corporate bond market overvalue bonds of sin companies? Financ. Res. Lett. 28, 165-170. https://doi.org/10.1016/j.frl.2018.04.018

Fabozzi, F.J., Ma, K.C., Oliphant, B.J., 2008. Sin stock returns. J. Portf. Manag. 35, 82. https://doi.org/10.3905/JPM.2008.35.1.82

Faul, F., Erdfelder, E., Buchner, A., Lang, A.-G., 2009. Statistical power analyses using G*Power 3.1: Tests for correlation and regression analyses. Behav. Res. Methods 41, 1149-1160. https://doi.org/10.3758/BRM.41.4.1149

Friesdorf, R., Conway, P., Gawronski, B., 2015. Gender Differences in Responses to Moral Dilemmas A Process Dissociation Analysis. Pers. Soc. Psychol. Bull. 0146167215575731. https://doi.org/10.1177/0146167215575731

Funder, D.C., Ozer, D.J., 2019. Evaluating Effect Size in Psychological Research: Sense and Nonsense. Adv. Meth. Pract. Psych. Sci. 2, 156-168. https://doi.org/10.1177/2515245919847202

Gawronski, B., Armstrong, J., Conway, P., Friesdorf, R., Hütter, M., 2017. Consequences, norms, and generalized inaction in moral dilemmas: The CNI model of moral decision-making. J. Pers. Soc. Psychol. 113, 343-376. https://doi.org/10.1037/pspa0000086

Guidi, M., Sogiakas, V., Vagenas-Nanos, E., Verwijmeren, P., 2020. Spreading the sin: An empirical assessment from corporate takeovers. Int. Rev. Financ. Anal. 71, 101535. https://doi.org/10.1016/j.irfa.2020.101535

Heinkel, R., Kraus, A., Zechner, J., 2001. The Effect of Green Investment on Corporate Behavior. J. Financ. Quant. Anal. 36, 431-449. https://doi.org/10.2307/2676219

Higgins, T., 2018. Tesla Shares Slide After More Executives Leave, Musk Interview. Wall Street Journal.

Hong, H., Kacperczyk, M., 2009. The price of sin: The effects of social norms on markets. J. Financ. Econ. 93, 15-36. https://doi.org/10.1016/j.jfineco.2008.09.001

Kant, I., 1948. Groundwork of the Metaphysic of Morals. HJ Paton. London: Hutchinson.

Luo, H.A., Balvers, R.J., 2017. Social Screens and Systematic Investor Boycott Risk. J. Financ. Quant. Anal. 52, 365-399. https://doi.org/10.1017/S0022109016000910

Mill, J.S., 2016. Utilitarianism, in: Seven Masterpieces of Philosophy. Routledge, pp. 337-383. 
New York Times, 2020. Goldman's Playbook for More Diverse Corporate Boards. The New York Times.

Niszczota, P., Kaszás, D., 2020. Robo-investment aversion. PLOS ONE 15, e0239277. https://doi.org/10.1371/journal.pone.0239277

Preacher, K.J., Hayes, A.F., 2004. SPSS and SAS procedures for estimating indirect effects in simple mediation models. Behavior Research Methods, Instruments, \& Computers 36, 717-731. https://doi.org/10.3758/BF03206553

Royzman, E.B., Baron, J., 2002. The Preference for Indirect Harm. Soc. Justice Res. 15, 165-184. https://doi.org/10.1023/A:1019923923537

Trinks, A., Scholtens, B., Mulder, M., Dam, L., 2018. Fossil Fuel Divestment and Portfolio Performance. Ecol. Econ. 146, 740-748. https://doi.org/10.1016/j.ecolecon.2017.11.036

Trinks, P.J., Scholtens, B., 2017. The Opportunity Cost of Negative Screening in Socially Responsible Investing. J. Bus. Ethics 140, 193-208. https://doi.org/10.1007/s10551-015-2684-3

van Rooij, M., Lusardi, A., Alessie, R., 2011. Financial literacy and stock market participation. J. Financ. Econ. 101, 449-472. https://doi.org/10.1016/j.jfineco.2011.03.006

van Staveren, I., 2014. The Lehman Sisters hypothesis. Camb. J. Econ. 38, 995-1014. https://doi.org/10.1093/cje/beu010

Weisskopf, J.-P., 2020. Breaking bad: An investment in cannabis. Financ. Res. Lett. 33, 101201. https://doi.org/10.1016/j.frl.2019.05.019 


\section{Appendix}

\section{Women oppose sin stocks more than men do}

Table A.1. Sex differences in ratings across industries.

\begin{tabular}{|c|c|c|c|c|c|c|c|c|c|c|}
\hline & \multicolumn{5}{|c|}{ Moral appropriateness } & \multicolumn{5}{|c|}{ Comfort levels } \\
\hline & Men & Women & $d$ & & $t$ & Men & Women & $d$ & & $t$ \\
\hline \multicolumn{11}{|l|}{ Sin stocks } \\
\hline Fur industry. Companies that manufacture, sell, or distribute fur products. & $3.38(2.09)$ & $2.39(1.80)$ & -0.51 & $* * *$ & -4.56 & $2.73(2.06)$ & $1.93(1.47)$ & -0.45 & $* * *$ & -3.97 \\
\hline $\begin{array}{l}\text { Animal Testing. Companies that do research or perform tests on animals for } \\
\text { medical and cosmetic reasons (to determine safety and efficacy of particular } \\
\text { products). }\end{array}$ & $3.14(2.02)$ & $2.22(1.69)$ & -0.50 & $* * *$ & -4.43 & $2.98(2.20)$ & $2.03(1.65)$ & -0.49 & $* * *$ & -4.34 \\
\hline $\begin{array}{l}\text { Tobacco. Companies involved in the production, processing and wholesale } \\
\text { distribution of tobacco products. }\end{array}$ & $3.27(2.02)$ & $2.38(1.87)$ & -0.46 & $* * *$ & -4.15 & $4.14(2.27)$ & $3.06(2.09)$ & -0.54 & $* * *$ & -4.83 \\
\hline $\begin{array}{l}\text { Gambling. Companies that manufacture, own, or operate gambling machines or } \\
\text { equipment, casinos, lotteries and betting activities. }\end{array}$ & $4.10(1.95)$ & $3.19(1.95)$ & -0.47 & $* * *$ & -4.26 & $3.35(2.24)$ & $2.24(1.90)$ & -0.49 & $* * *$ & -4.45 \\
\hline $\begin{array}{l}\text { Controversial Weapons. Companies involved in nuclear, biological, chemical } \\
\text { weapons, cluster munitions, and antipersonnel mines. }\end{array}$ & $2.76(1.98)$ & $2.10(1.56)$ & -0.38 & $* * *$ & -3.31 & $3.14(2.30)$ & $2.22(1.81)$ & -0.45 & $* * *$ & -3.96 \\
\hline $\begin{array}{l}\text { Adult Entertainment. Companies targeted at the production or distribution of } \\
\text { sexually explicit products and services, i.e., X-rated films, online products, } \\
\text { production studios, printed materials, TV or radio programs, and adult clubs or } \\
\text { bars. }\end{array}$ & $3.97(2.11)$ & $3.21(2.07)$ & -0.36 & $* *$ & -3.30 & $4.05(2.25)$ & $2.90(2.09)$ & -0.53 & $* * *$ & -4.78 \\
\hline $\begin{array}{l}\text { Abortion/Abortifacients. Companies owning or operating facilities where } \\
\text { abortions are performed, abortion providers, abortifacient manufacturers. }\end{array}$ & $3.93(2.16)$ & $3.78(2.29)$ & -0.06 & & -0.59 & $3.56(2.21)$ & $3.54(2.42)$ & -0.01 & & -0.06 \\
\hline \multicolumn{11}{|l|}{ Conventional stocks } \\
\hline $\begin{array}{l}\text { Water Utilities. Companies that distribute water to consumers, also by being } \\
\text { involved in water treatment. }\end{array}$ & $5.93(1.51)$ & $5.67(1.57)$ & -0.17 & & -1.55 & $6.14(1.29)$ & $5.79(1.45)$ & -0.25 & * & -2.30 \\
\hline $\begin{array}{l}\text { Semiconductors/Semiconductor Equipment. Companies that manufacture } \\
\text { semiconductors or semiconductor equipment. }\end{array}$ & $5.63(1.72)$ & $5.44(1.56)$ & -0.12 & & -1.04 & $5.88(1.60)$ & $5.68(1.54)$ & -0.13 & & -1.17 \\
\hline $\begin{array}{l}\text { Construction/Engineering. Companies engaged primarily in non-residential } \\
\text { construction, as well as civil engineering companies. }\end{array}$ & $5.86(1.60)$ & $5.76(1.43)$ & -0.07 & & -0.61 & $6.08(1.42)$ & $5.93(1.35)$ & -0.11 & & -1.02 \\
\hline $\begin{array}{l}\text { Air Freight/Logistics. Companies providing air freight transportation, air } \\
\text { courier, and air logistics services. }\end{array}$ & $5.80(1.64)$ & $5.72(1.49)$ & -0.05 & & -0.49 & $5.92(1.53)$ & $5.77(1.58)$ & -0.10 & & -0.89 \\
\hline
\end{tabular}




\begin{tabular}{|c|c|c|c|c|c|c|c|c|}
\hline & \multicolumn{4}{|c|}{ Moral appropriateness } & \multicolumn{4}{|c|}{ Comfort levels } \\
\hline & Men & Women & $d$ & $t$ & Men & Women & $d$ & $\boldsymbol{t}$ \\
\hline $\begin{array}{l}\text { Road/Rail. Companies providing railroad and trucking transportation of } \\
\text { passengers or goods. }\end{array}$ & $5.90(1.61)$ & $5.81(1.50)$ & -0.06 & -0.53 & $6.07(1.37)$ & $6.02(1.26)$ & -0.04 & -0.36 \\
\hline Marine. Companies providing maritime transportation of passengers or goods. & $5.50(1.72)$ & $5.53(1.52)$ & 0.02 & 0.16 & $5.80(1.57)$ & $5.71(1.47)$ & -0.06 & -0.53 \\
\hline $\begin{array}{l}\text { Household Durables. Companies that manufacture consumer electronics, } \\
\text { household appliances, houseware etc. }\end{array}$ & $5.88(1.57)$ & $5.92(1.42)$ & 0.03 & 0.26 & $6.05(1.4)$ & $6.12(1.16)$ & 0.05 & 0.475 \\
\hline
\end{tabular}

Notes: Rating are from 1 to 7. Standard deviations are shown in parentheses. $d$ denotes Cohen's $d ; t$ denotes $t$-statistic $* * *, * *, *$ denote significant difference between sexes at $0.1,1$ and $5 \%$ (t-test). 
Exploratory study

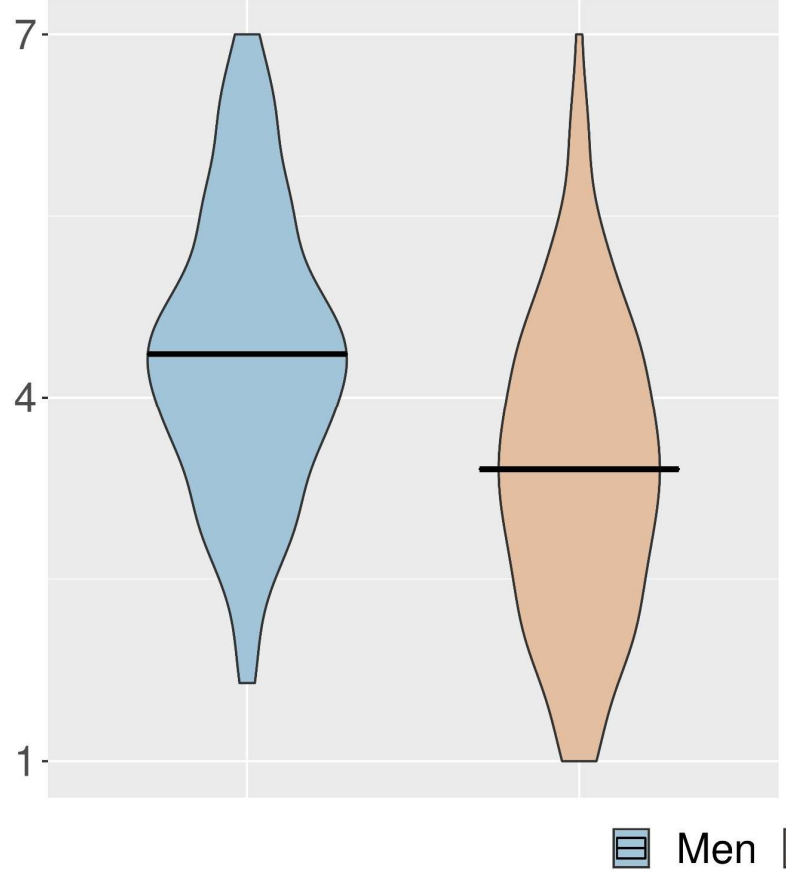

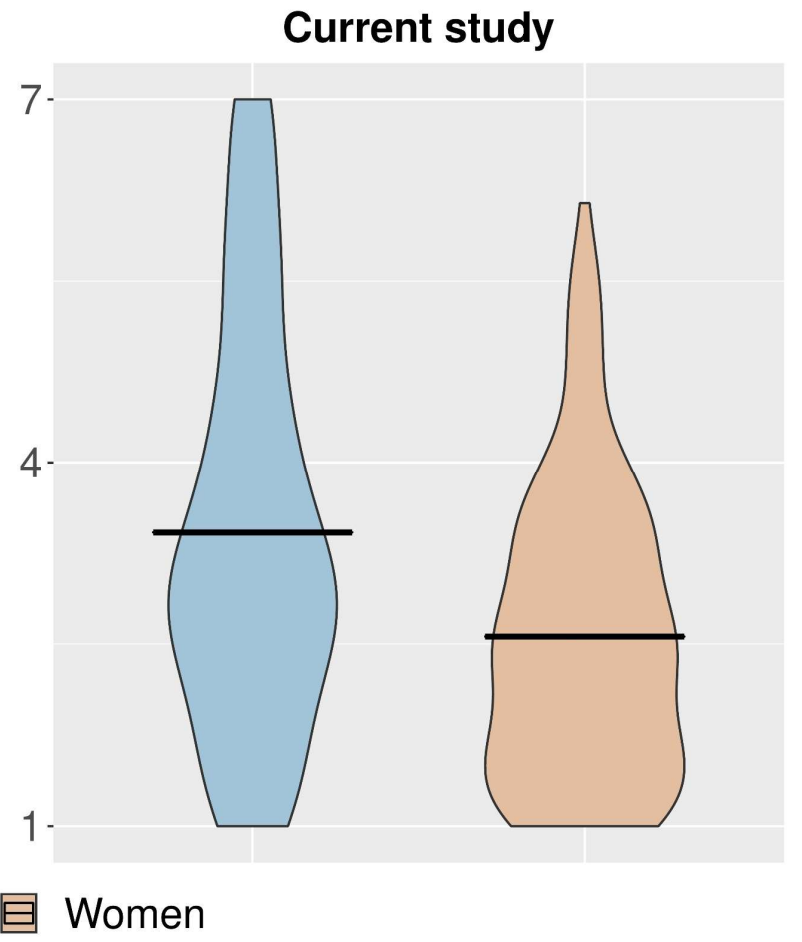

Fig. A.1. Comfort levels of holding stocks in earlier and current study. Horizontal bars indicate means. The left panel shows data from an earlier study (Niszczota and Kaszás, 2020) on which the current study is based on (14 sin industries from Trinks and Scholtens (2017)), and the right panel shows data for the current study ( 7 sin industries with which participants felt the least comfortable with in the earlier study). 